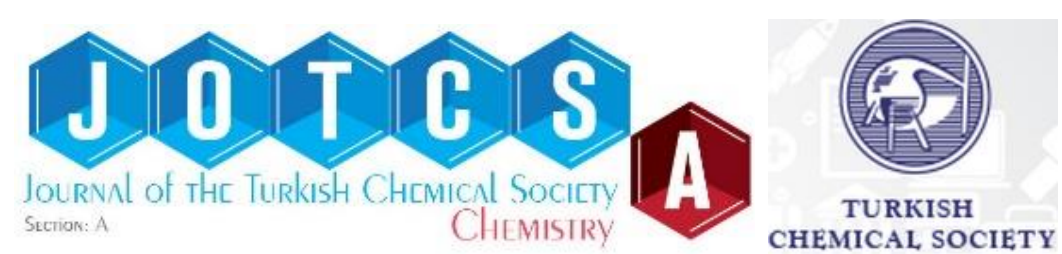

\title{
Synthesis, Characterization, and Cytotoxic Activities of a Schiff Base Ligand and Its Binuclear Copper(II) and Manganese(III) Complexes
}

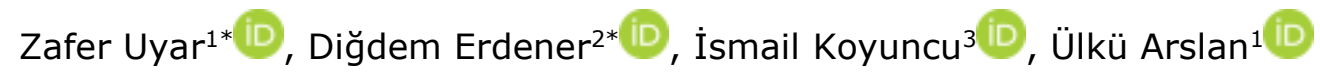 \\ ${ }^{1}$ Department of Chemistry, Faculty of Science and Arts, Harran University, 63300, \\ Şanlıurfa, Turkey \\ ${ }^{2}$ Department of Chemistry, Faculty of Science and Arts, Çanakkale Onsekiz Mart \\ University, 17100, Çanakkale, Turkey \\ ${ }^{3}$ Department of Biochemistry, Faculty of Medicine, Harran University, 63300, Şanlıurfa, \\ Turkey
}

\begin{abstract}
A novel symmetrical $\mathrm{N}_{2} \mathrm{O}_{2}$ type Schiff base (1) and its copper (II) (2) and manganese (III) (3) complexes were synthesized and characterized by spectroscopic, analytical, and magnetic susceptibility studies. Spectroscopic and magnetic susceptibility studies suggested that copper and manganese ions are in $2+$ and $3+$ states and their complexes have a binuclear double stranded helical structure in the form of 2:2 (metal to ligand) stoichiometry. Cytotoxic effects of the ligand and its metal complexes against MCF7 (human breast cancer cell line), DLD-1 (human colorectal cancer cell line), ECC-1 (human endometrium cancer cell line), DU-145 (human prostate cancer line), MDA-MB231 (human breast cancer cell line), PC-3 (human prostate cancer line) and HEK293 (normal cells) were evaluated by determining their cellular viability using the colorimetric 3-(4,5dimethylthiazole-2-yl)-2,5-biphenyl tetrazolium bromide (MTT) assay. It has been found that cytotoxicity of the ligand was significantly enhanced towards cancer cells and declined towards normal HEK293 cells by metal chelation. Copper complex yielded better results in comparison with manganese complex. Particularly, copper complex showed a selective cytotoxicity, harming the cancerous cell lines while not impairing the normal cells, which is considered as the key to the future of cytotoxic therapy.
\end{abstract}

Keywords: $\mathrm{N}_{2} \mathrm{O}_{2}$ Schiff base; transition metal complexes; binuclear complexes; selective cytotoxicity; metal chelation.

Submitted: July 17, 2017. Accepted: September 19, 2017.

Cite this: Uyar Z, Erdener D, Koyuncu İ, Arslan Ü. Synthesis, Characterization, and Cytotoxic Activities of a Schiff Base Ligand and Its Binuclear Copper(II) and Manganese(III) Complexes. JOTCSA. 2017;4(3):963-80.

DOI: $10.18596 /$ jotcsa.329108.

*Corresponding authors. E-mails: zaferuyar@gmail.com, digdem erdener@hotmail.com. 


\section{INTRODUCTION}

Schiff bases have been serving as versatile and practical ligands in the field of coordination chemistry since they were synthesized for the first time by Hugo Schiff in 1864 (1). Metal complexes of Schiff bases have played a major role in the advancement of coordination chemistry whose field of application varies from physicochemical studies (2) to biological aspects $(3,4)$. Both symmetrical and non-symmetrical Schiff bases have been widely used as ligands to prepare metal complexes (5). Tetradentate symmetrical $\mathrm{N}_{2} \mathrm{O}_{2}$ Schiff bases and their metal complexes also contributed to the development of coordination chemistry immensely because of their structural variety, preparative accessibility, and bioactivity $(6,7)$.

Cytotoxicity of the Schiff bases has been receiving considerable attention ever since the discovery of their effectiveness at inhibiting proliferation of cancer cells (8-11). Discovery of novel potent, selective, and less toxic anticancer agents remains one of the most active areas in the field of medicinal chemistry and drug design (12). Development of resistance by tumor cells against the existing anticancer drugs and increasing mortality rates due to cancer each year keeps this research window open for new chemotherapeutics (13). Having various biological activities despite being small molecules, transition metal complexes of Schiff bases have also aroused great attention to find new chemotherapeutic drugs. Numerous studies have reported that Schiff bases have shown mild to good cytotoxicity against various malignant tumors (14-18) and the metal included in the complex has a significant impact on the effectiveness of the compound $(14,17,19-24)$. However, very few studies dealing with the cytotoxicity of the $\mathrm{N}_{2} \mathrm{O}_{2}$ type Schiff bases have been reported. With this in mind, we synthesized a novel symmetrical $\mathrm{N}_{2} \mathrm{O}_{2}$ type Schiff base ligand and its copper and manganese complexes and evaluated the effect of these metals on cytotoxicity against six malignant tumor cell lines and a healthy cell line. In the literature, a similar ligand and its some metal complexes have been studied regarding the structure, magnetic and luminescent properties, antimicrobial, and antioxidant activities by different groups (25-27). We have used a different aldehyde in the synthesis of the Schiff base and utilized a different synthetic approach to prepare the complexes by using different metal salts and solvent. We obtained similar binuclear double-helical structures for both complexes. Although the structural architecture of the copper complex is the same as the reported complexes in the above-mentioned studies, the structure of manganese complex is different. To the best of our knowledge, this is the first report of the double stranded helical structure for this type of manganese complex and cytotoxic activities for these types of metal complexes. 


\section{MATERIALS AND METHODS}

\section{Materials}

All chemicals for the syntheses and the solvents used were of analytical grade quality from commercial sources and were used without further purification. Fourier transform infrared (FT-IR) spectra were measured with a Perkin-Elmer Spectrum Two FT-IR spectrometer in the range $4000-400 \mathrm{~cm}^{-1}$. Melting points were determined on an Electro Thermal IA 9100 apparatus using a capillary tube. ${ }^{1} \mathrm{H}-\mathrm{NMR}$ and ${ }^{13} \mathrm{C}-\mathrm{NMR}$ spectra of the Schiff base were recorded at room temperature on a resolution Fourier transform Bruker Biospin $300 \mathrm{MHz}$ spectrometer with tetramethylsilane as an internal standard. Elemental analyses of the compounds were carried out by using an LECO CHNS-932 analyzer. UV-Vis absorption spectra were measured in a $1 \mathrm{~cm}$ path-length quartz cell by Perkin Elmer Lambda 35 spectrophotometer in the wavelength 250-500 nm. NMR spectra of the ligand are presented in supplementary material to this paper. The mass spectra (LC-MS) were measured using an Agilent LC-MS/MS spectrometer. Magnetic susceptibilities were determined on a Sherwood Scientific Magnetic Susceptibility Balance (Model MK1) at room temperature $\left(32{ }^{\circ} \mathrm{C}\right)$ using $\mathrm{Hg}\left[\mathrm{Co}(\mathrm{SCN})_{4}\right]$ as a calibrant; diamagnetic corrections were calculated from Pascal's constants (28).

MCF-7, DLD-1, ECC-1, DU145, PC3, and MDA-MB-231 human cancer cell lines and HEK293 cells were purchased from the American Tissue Culture Collection (ATCC, USA). The supplemented RPMI 1640 medium and DMEM: F12 were obtained from Biochrom, USA. The supplements or antibiotics such as fetal bovine serum (FBS), penicillin/streptomycin $(\mathrm{P} / \mathrm{S})(100 \mu \mathrm{g} / \mathrm{mL}), \mathrm{L}$-glutamine, and fluorouracil (5-FU) were purchased from SigmaAldrich, USA. The cells were cultured in a $\mathrm{CO}_{2}$ incubator with $25 \mathrm{~cm}^{3}$ tissue culture flasks (Nunc, Denmark), which was observed routinely under an inverted microscope (Olympus, Japan) for any contamination and seeded into a 96-well flat bottom microtiter plate (Nunc, Denmark). The compounds were dissolved in dimethyl sulfoxide (DMSO Molecular Biology Grade, >99.9\%) from Sigma-Aldrich, USA. Absorbance was measured at $570 \mathrm{~nm}$ using a microplate reader (SpectraMax M5 microplate reader of Molecular Devices, USA). The cells were cultured in a tissue culture flask in $5 \% \mathrm{CO}_{2}$ incubator kept at $37{ }^{\circ} \mathrm{C}$ in a humidified atmosphere and observed routinely under an inverted microscope from any contaminations. Each fresh medium was replaced every 2 or 3 days until cell confluence was achieved and the cells were detached by using trypsin EDTA.

\section{Synthesis of the ligand (1)}

2-Hydroxy-6-methoxybenzaldehyde $(0.31 \mathrm{~g} ; 2.04 \mathrm{mmol})$ was dissolved in $15 \mathrm{~mL}$ of ethanol in a $100 \mathrm{~mL}$ round-bottom flask equipped with a magnetic stirring bar. To this solution was 
added 4,4'-oxydianiline $(0.204 \mathrm{~g} ; 1.02 \mathrm{mmol})$ and the reaction mixture was stirred at room temperature for $2 \mathrm{~h}$. The excess solvent was removed with a rotary evaporator and compound $\mathbf{1}$ was obtained as yellowish solid.

Yellow solid, $\mathrm{mp}: 118{ }^{\circ} \mathrm{C}$, yield: $86 \%$, chemical formula: $\mathrm{C}_{28} \mathrm{H}_{24} \mathrm{~N}_{2} \mathrm{O}_{5}, \mathrm{M}_{\mathrm{w}}: 468.51$, LC$\mathrm{MS}(\mathrm{ESI}): 469[\mathrm{M}+\mathrm{H}]^{+}$, IR $\left(\mathrm{Umax}_{\mathrm{ma}} \mathrm{cm}^{-1}\right) \mathrm{v}(\mathrm{C}=\mathrm{N})$ 1615, $\mathrm{v}(\mathrm{C}=\mathrm{C})$ 1579, $\mathrm{v}(\mathrm{C}-\mathrm{N})$ 1445, $\mathrm{v}(\mathrm{C}-\mathrm{O})$ 1254. ${ }^{1} \mathrm{H}$ NMR (DMSO): $\delta 12.39(\mathrm{~s}, 2 \mathrm{H}, \mathrm{Ar}-\mathrm{O}-\mathrm{H}), 8.08(\mathrm{~s}, 2 \mathrm{H}, \mathrm{Ar}-\mathrm{CH}=\mathrm{N}), 6.03-6.60(\mathrm{~m}$, $14 \mathrm{H}, \mathrm{Ar}-\mathrm{H}), 2.95\left(\mathrm{~s}, 6 \mathrm{H}, \mathrm{Ar}-\mathrm{OCH}_{3}\right) .{ }^{13} \mathrm{C}$ NMR (DMSO): $\delta 163.06(\mathrm{Ar}-\underline{\mathrm{C}}=\mathrm{N}) ; 155.80$ ( $\underline{\mathrm{Ar}}-\mathrm{O}-$ $\underline{\mathrm{Ar}}) ; 150.64(\underline{\mathrm{Ar}}-\mathrm{OH}) ; 148.09$ ( $\underline{\mathrm{Ar}}-\mathrm{OMe}) ; 143.62$ ( $\underline{\mathrm{Ar}}-\mathrm{N}=)$; 124.05, 123.29, 119.72, 119.44, 118.80, $115.63(\underline{\mathrm{Ar}}-\mathrm{H}) ; 56.05\left(-\mathrm{O} \mathrm{CH}_{3}\right)$. Anal. Calcd. for $\mathrm{C}_{28} \mathrm{H}_{24} \mathrm{~N}_{2} \mathrm{O}_{5}(\%): \mathrm{C}, 71.78 ; \mathrm{H}, 5.16$; $\mathrm{N}, 5.98$. Found (\%): C, 71.45; H, 5.23; N, 5.85 .

\section{General Procedure for the Preparation of Metal Complexes (2 and 3)}

To a round-bottom flask equipped with a water condenser and magnetic stirring bar was added ligand (1) $(0.158 \mathrm{mmol})$ and the respective metal chloride salt, $\mathrm{MCl}_{2},(0.158 \mathrm{mmol})$. $20 \mathrm{~mL}$ of methanol was added to dissolve the reaction mixture. After refluxed for $24 \mathrm{~h}$, the reaction mixture was allowed to cool to room temperature. The solution was passed through a No: 1 Whatman filter paper and the residue was washed with methanol and then ether. The resultant solid was dried under vacuum.

$\mathrm{Cu}(\mathrm{II})$ complex (2): Brown solid, yield: $73 \%$, chemical formula: $\mathrm{C}_{56} \mathrm{H}_{44} \mathrm{Cu}_{2} \mathrm{~N}_{4} \mathrm{O}_{10}$, $M_{w}: 1060.08, L C-M S(E S I): 1061.2[M+H]^{+}, I R\left(u_{\max }, \mathrm{cm}^{-1}\right) \mathrm{v}(\mathrm{C}=\mathrm{N}) 1611, \mathrm{v}(\mathrm{C}=\mathrm{C}) 1545, \mathrm{v}(\mathrm{C}-$ N) $1459, \mathrm{v}(\mathrm{C}-\mathrm{O})$ 1237. Anal. Calcd. for $\mathrm{C}_{56} \mathrm{H}_{44} \mathrm{Cu}_{2} \mathrm{~N}_{4} \mathrm{O}_{10}(\%): \mathrm{C}, 63.45 ; \mathrm{H}, 4.18 ; \mathrm{N}, 5.29$. Found (\%): C, 62.66; H, 4.48; N, 5.03.

$\mathrm{Mn}$ (III) complex (3): Dark orange solid, yield: $67 \%$, chemical formula: $\mathrm{C}_{56} \mathrm{H}_{50} \mathrm{Cl}_{2} \mathrm{Mn}_{2} \mathrm{~N}_{4} \mathrm{O}_{13}$, $M_{w}: 1168, L C-M S(E S I): 1169.1[M+H]^{+}, I R\left(U_{\max }, \mathrm{cm}^{-1}\right) \mathrm{v}(\mathrm{C}=\mathrm{N}) 1614, \mathrm{v}(\mathrm{C}=\mathrm{C}) 1500, \mathrm{v}(\mathrm{C}-\mathrm{N})$ 1453, v(C-O) 1231. Anal. Calcd. for $\mathrm{C}_{56} \mathrm{H}_{50} \mathrm{Cl}_{2} \mathrm{Mn}_{2} \mathrm{~N}_{4} \mathrm{O}_{13}$ (\%): C, 57.60; $\mathrm{H}, 4.32 ; \mathrm{N}, 4.80$. Found (\%): C, 56.80; H, 4.71; N, 5.01.

\section{Cytotoxicity Assay and Determination of $\mathbf{I C}_{50}$}

The effect of the compounds on the cellular viability was determined using the colorimetric 3-(4,5-dimethylthiazole-2-yl)-2,5-biphenyl tetrazolium bromide (MTT) assay. This method measures mitochondrial activity based on the reductive cleavage of the yellow tetrazolium salt to a purple formazan compound by the dehydrogenase activity of intact mitochondria. Briefly, cells ( $1 \times 10^{5}$ cells/well) were seeded in 96-well microtiter plates (Nunc, Denmark). After exposure to various concentrations of compounds for $24 \mathrm{~h}$, cells were washed once with phosphate-buffered saline (PBS) before addition of $100 \mu \mathrm{L}$ of serum-free medium 
containing $5 \mathrm{mg} / \mathrm{mL}$ of MTT (Sigma, Missouri) to each well. After incubation for $4 \mathrm{~h}$, the supernatant was removed and the formazan product obtained was dissolved in $100 \mu \mathrm{L}$ of DMSO; (Sigma). The mixture was stirred for $20 \mathrm{~min}$ on a microtiter plate shaker and the absorbance was read at $570 \mathrm{~nm}$. Cell viability was expressed as the percentage of untreated cells that served as the control group and was designated as $100 \%$ according to the formula below.

$\%$ Viable Cells $=\frac{(\text { The absorbance of the treated cells })-(\text { The absorbance of the blank })}{(\text { The absorbance of the control })-(\text { The absorbance of the blank })} \times 100$ (Eq. 1$)$

Cytotoxicity was expressed as mean percentage increase relative to the unexposed control \pm SD. Control values were set at $0 \%$ cytotoxicity. Cytotoxicity data (where appropriate) were fitted to a sigmoidal curve and a four-parameter logistic model was used to calculate the $\mathrm{IC}_{50}$, which is the concentration of material causing $50 \%$ inhibition in comparison to the untreated controls. The mean $\mathrm{IC}_{50}$ is the concentration of material that reduces cell growth by $50 \%$ under the experimental conditions and is the average of at least three independent measurements that were reproducible and statistically significant. The IC 50 values were reported at $\pm 95 \%$ confidence intervals ( $\pm 95 \% \mathrm{CI}$ ). This analysis was performed with Graph Pad Prism (San Diego, CA, USA).

\section{RESULTS AND DISCUSSION}

\section{Synthesis of Schiff Base and its Metal Complexes}

The Schiff base was synthesized by condensation of 2-hydroxy-6-methoxybenzaldehyde with 4,4'-oxydianiline. Copper and manganese complexes were prepared by the reaction of $\mathrm{CuCl}_{2}$ and $\mathrm{MnCl}_{2}$ with the Schiff base using a 1:1 ratio, respectively. The schiff base and complexes are stable in air and could be stored without any appreciable change. The complexes are soluble in THF, DMF, and DMSO. The colors of the ligand, copper, and manganese complexes are yellow, brown, and dark orange, respectively. The structures of the compounds were determined by NMR, FT-IR, UV, LC-MS, magnetic susceptibility and MM2 calculation studies. 
<smiles>COc1cccc(O)c1COCCO</smiles>

$\mathrm{OH}$<smiles>COc1cccc(O)c1/C=N/c1ccc(Oc2ccc(/N=C/c3c(O)cccc3OC)cc2)cc1</smiles>

$\mathrm{MCl}_{2}$ $\mathrm{CH}_{3} \mathrm{OH}$

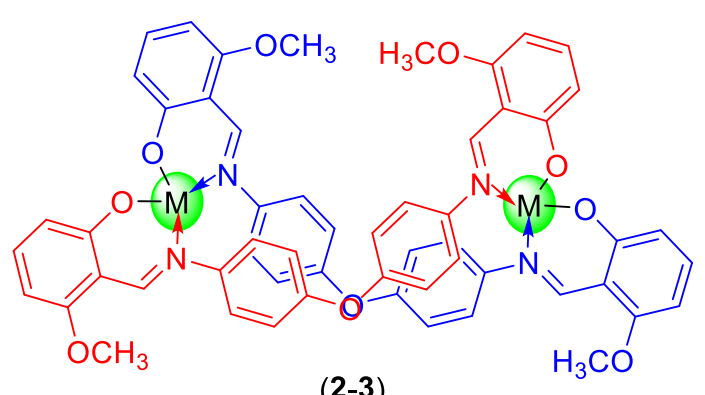

(2-3)

$$
\mathrm{M}: \begin{aligned}
& \mathrm{Cu} \\
& \mathrm{Mn} \cdot 2 \mathrm{H}_{2} \mathrm{O}(\mathbf{3})
\end{aligned}
$$

Scheme 1. The synthetic route for the Schiff base ligand (1) and its copper (2) and manganese (3) complexes.

\section{NMR Studies}

${ }^{1} \mathrm{H}$-NMR and ${ }^{13} \mathrm{C}$-NMR spectra of the ligand are presented in supplementary data (Figures $\mathrm{S} 1-\mathrm{S} 2$ ). In the ${ }^{1} \mathrm{H}-\mathrm{NMR}$ spectra of ligand (1) the phenolic - $\mathrm{OH}$ group of 2-hydroxy-6methoxybenzaldeyde signal appears as a singlet at $\delta=12.39 \mathrm{ppm}$. The imine protons are observed at $\delta=8.08 \mathrm{ppm}$ as a singlet. The phenyl protons resonate at $\delta=6.03-6.60 \mathrm{ppm}$ as multiplet. The $\mathrm{O}-\mathrm{CH}_{3}$ protons of the compound gave a singlet at $\delta=2.95 \mathrm{ppm}$.

According to ${ }^{13} \mathrm{C}-\mathrm{NMR}$ spectra, the ligand has 12 signals. The aromatic carbons are observed between 115-156 ppm. The aliphatic $\mathrm{Ar} \underline{\mathrm{C}} \mathrm{H}=\mathrm{N}-\mathrm{Ar}$ and $\underline{\mathrm{C}} \mathrm{H}_{3} \mathrm{O}$ carbons are seen at 163.06 and 56.05 ppm, respectively.

\section{FT-IR, Electronic, and LC-MS Spectra}

IR spectra of ligand and its complexes are given in supplementary data (Figure S3). IR spectra of the ligand and its copper and manganese complexes exhibit various bands in the $4000-400 \mathrm{~cm}^{-1}$ region. The absence of an $\mathrm{O}-\mathrm{H}$ stretching band of the free ligand in the 3200-3800 region supports the presence of an intramolecular hydrogen bond between $\mathrm{OH}$ and $-\mathrm{C}=\mathrm{N}$ group. The IR spectrum of ligand shows a sharp and intense peak with the maximum at $1614 \mathrm{~cm}^{-1}$ which can be assigned to $\mathrm{v}(\mathrm{C}=\mathrm{N})$ vibration $(29,30)$. In the copper and manganese complexes, this band is slightly shifted to lower frequencies of 1611 and $1612 \mathrm{~cm}^{-1}$, respectively, due to the coordination of nitrogen atoms in imine $(-\mathrm{C}=\mathrm{N})$ groups to the metal ion. The phenolic $\mathrm{C}-\mathrm{O}$ stretching frequencies appear as strong bands at 1257 
and $1196 \mathrm{~cm}^{-1}$ in the spectrum of the free ligand as reported for similar salen-type ligands $(31,32)$. These bands shifted to 1242 and $1178 \mathrm{~cm}^{-1}$ for the copper complex and 1233 and $1172 \mathrm{~cm}^{-1}$ for the manganese complex. This bathochromic shift to an extend of $24 \mathrm{~cm}^{-1}$ in the phenolic $\mathrm{C}-\mathrm{O}$ stretching vibration band confirms the coordination of the phenolic oxygen to the metal ion (33-35). A new intense band observed at $754 \mathrm{~cm}^{-1}$ in the spectrum of manganese complex indicates the presence of coordinated water molecules to $\mathrm{Mn}$ metal in the complex (36). This is further supported by the appearance of a broad $\mathrm{OH}$ peak between $3200-3800 \mathrm{~cm}^{-1}$ in the spectrum of manganese complex. The spectrum of copper complex remained unchanged in the corresponding regions confirming that no water molecule is involved in the formation of copper complex.

The electronic spectra of the ligand and its metal complexes were recorded in DMSO between 250 and $500 \mathrm{~nm}$ (Figure 1). UV-Vis spectrum of the free ligand exhibits two absorption peaks at 280 and $332 \mathrm{~nm}$. The intense peak at $280 \mathrm{~nm}$ can be assigned to the $\Pi \rightarrow \Pi^{*}$ transition of the aromatic rings. The azomethine $\Pi \rightarrow \Pi^{*}$ transition band appears at $332 \mathrm{~nm}$ (37). The electronic spectra of the metal complexes have a similar profile. The vibrations found below $290 \mathrm{~nm}$ originate from $n \rightarrow \Pi^{*}$ transitions associated with the phenolic chromophores whereas the absorption in the range of $300-350 \mathrm{~nm}$ can be attributed to $\Pi \rightarrow \Pi^{*}$ transitions of the $\mathrm{C}=\mathrm{N}$ bonds. The absorption band in the region of $330 \mathrm{~nm}$ for $\mathrm{Cu}$ (II) indicates a four-coordinate square planar geometry of $\mathrm{Cu}$ (II) $(38,39)$. The band in the visible region at about $360-400 \mathrm{~nm}$ can be attributed to ${ }^{2} \mathrm{~B}_{1 \mathrm{~g}} \rightarrow{ }^{2} \mathrm{E}_{\mathrm{g}}$ transition (31). The bands observed above $400 \mathrm{~nm}$ for both complexes are assigned to the charge transfer transitions from the filled $n$ orbital of the bridging phenolic oxygen atoms to the vacant $d$ orbital of metal ions (39).

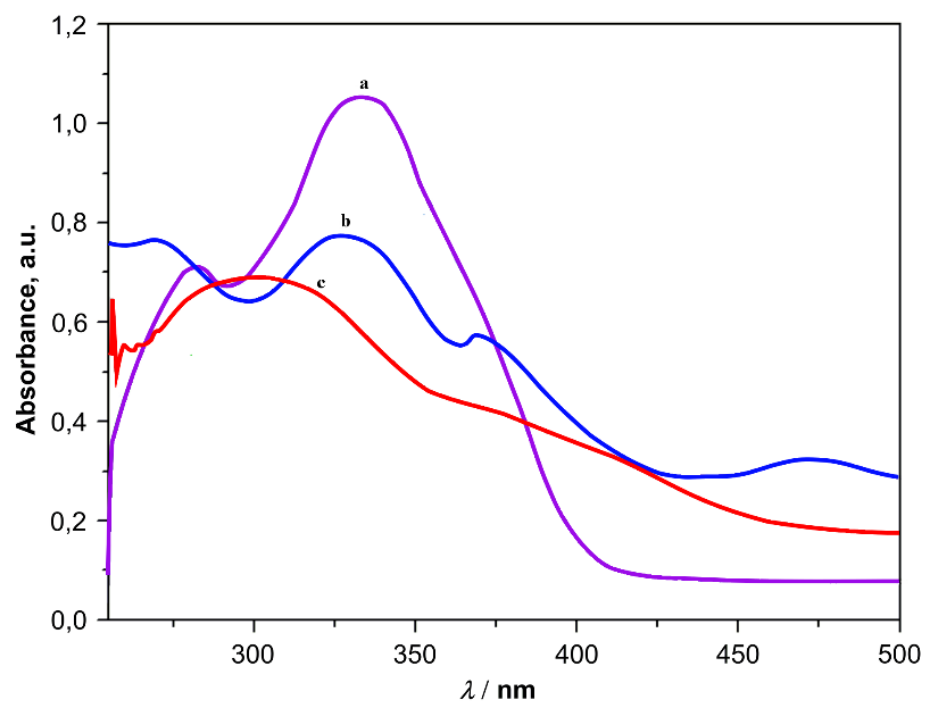

Figure 1. Electronic spectra of free ligand (a), copper complex (b), and manganese complex (c) (solution in DMSO) 
The LC-MS spectra of the Schiff base ligand (1) and its $\mathrm{Cu}$ (II) and $\mathrm{Mn}$ (III) complexes (23) show the major fragment ions and the isotopic distributions of different intensities confirming their molecular weights. The peak at $m / z=469[\mathrm{M}+\mathrm{H}]^{+}$is ascribed to the molecular weight of the ligand. (Figure S4). The LC-MS spectra of the binuclear copper complex (2) exhibited a major peak attributed to the molecular ions at $\mathrm{m} / \mathrm{z}=1061.20$ $[\mathrm{M}+\mathrm{H}]^{+}$for $\left[\mathrm{Cu}_{2} \mathrm{~L}_{2}\right]$ (Figure S5). The LC-MS spectra of the binuclear manganese complex has a major peak at $\mathrm{m} / \mathrm{z}=1169.10[\mathrm{M}+\mathrm{H}]^{+}$for $\left[\mathrm{Mn}_{2} \mathrm{~L}_{2} \mathrm{Cl}_{2}\left(\mathrm{H}_{2} \mathrm{O}\right)_{2}\right] \cdot \mathrm{H}_{2} \mathrm{O}$ (Figure S6). These results are perfectly consistent with the calculated molecular weights of the target compounds.

\section{Magnetic Susceptibility Studies}

Magnetic susceptibility measurement provides satisfactory data to estimate the structure of the metal complexes. Magnetic moment measurements of the complexes were carried out at ambient temperature $\left(32^{\circ} \mathrm{C}\right)$ using $\mathrm{Hg}\left[\mathrm{Co}(\mathrm{SCN})_{4}\right]$ as a calibrant. Both complexes have paramagnetic characters. The magnetic moments for binuclear double-helical structures of copper and manganese complexes were found to be 2.7 B.M. and 8.1 B.M., respectively. These values are only slightly lower than the theoretical values of 2.8 B.M. and 8.9 B.M. for a binuclear $\mathrm{Cu}$ (II) and high spin $\mathrm{Mn}$ (III) ion, respectively, most probably due to a weak antiferromagnetic interaction. These results confirm that copper ion is in $2+$ oxidation state with $\mathrm{d}^{9}$ configuration having one unpaired electron and manganese ion is in $4+$ oxidation state with $\mathrm{d}^{4}$ configuration corresponding to four high-spin unpaired electrons. These data suggest that the complexes are in the form of 2:2 (metal to ligand) stoichiometry and confirm a square planar geometry around $\mathrm{Cu}$ ion and an octahedral geometry around $\mathrm{Mn}$ ion. This data is consistent with the elemental analysis results.

The structures of the complexes were further supported by the molecular mechanics (MM2) calculations. MM2 calculation indicates that the two N-donors of the ligand cannot be closer than about $9 \AA$ which naturally means a tetradentate chelation of the ligand is unachievable. Thus, each of two ligands should bind as a bidentate ligand to two different metal centers to form a binuclear double stranded helicate complex (Figure 2). MM2 calculation also demonstrates that $\mathrm{M}-\mathrm{O}$ and $\mathrm{M}-\mathrm{N}$ bond distances in these dinuclear distorted double-stranded helicates are approximately $1.846 \AA$ and $1.805 \AA$, respectively, which are in perfect consistency with the literature (25-27). When a tetradentate ligand fails to coordinate tetradentally to a metal atom due to a long spacer between the coordination sites, its bidentate coordination to one or two metal atoms is well known.

The structure of our copper and manganese complexes derived from bis(N-(6-methoxysalicylidene)-4-aminophenyl)ether Schiff base could also be supported by the similar 
complexes reported in the literature. Two different studies by Paula Cucos (25) and QiMeige Hasi (26) reported that copper complex prepared from bis(N-(3-methoxysalicylidene)-4-aminophenyl)ether Schiff base had a binuclear double stranded helicates with copper ion in $2+$ state. Our Schiff base only differs from these reported ones in that it has the methoxy groups at 6th carbons of the phenyl moieties instead of the 3rd carbons. So, it is only reasonable to expect our complex would have the same binuclear double stranded structure since the methoxy substituents are not involved in the coordination with the metal that might lead to a different structure formation. The former group also employed $\mathrm{Co}$ (II) and Zn(II) metals as assembling cations and found that their Schiff base formed the same complex structures with these metals as well. The latter group also prepared manganese complex of the Schiff base. Unlike the binuclear $M_{2} L_{2}$ type complexes formed by the metals mentioned above, the manganese metal created an ML2 type complex and surprisingly, manganese ion was not coordinated to imino nitrogen atoms of the ligand. Instead, manganese(III) ion was coordinated to six oxygen atoms from two hydroxy and two methoxy groups of the two ligands and two water molecules. So, the manganese complex contained one manganese(III) ion, two ligands, and two water molecules. The occurrence of this phenomenon in our case is simply not possible because our methoxy and hydroxyl groups are not close enough to each other to be able to trap the manganese ion. However, methoxy and hydroxyl groups in their Schiff base were adjacent to each other.
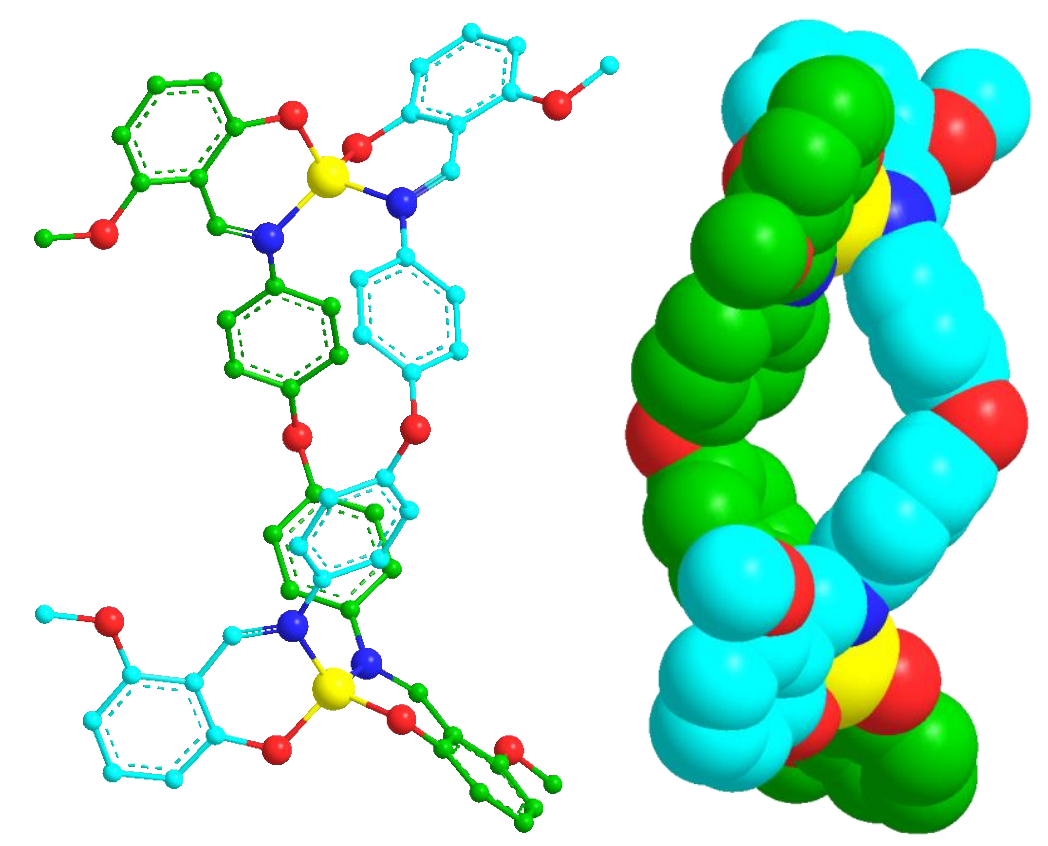

Figure 2. View of the molecular structure (left) and space-filling representation (right) of metal complexes $\mathbf{2}$ and $\mathbf{3}$ demonstrating double-stranded helical structure. Each strand is colored differently and hydrogen atoms are omitted for the clarity of the structure. 


\section{In vitro Cytotoxic Activity}

Table 1. I $\mathrm{C}_{50}$ values for the tested cell lines following $\mathbf{1}, \mathbf{2}, \mathbf{3}$, and $5-\mathrm{FU}$ exposures.

\begin{tabular}{lcccc}
\hline \multirow{2}{*}{ Cell lines } & \multicolumn{4}{c}{ IC $_{\mathbf{5 0}}$ values, $\boldsymbol{\mu M}}$. \\
\cline { 2 - 5 } & $\mathbf{1}$ & $\mathbf{2}$ & $\mathbf{3}$ & $\mathbf{5 - F U}$ \\
\hline MCF-7 & 1000 & 43.4 & 273.6 & 58,44 \\
DLD-1 & 219.4 & 142.9 & 193.8 & 39,34 \\
ECC-1 & 386.9 & 100 & 304.8 & 34,4 \\
DU-145 & 177.2 & 93.5 & 182.9 & 50,22 \\
PC3 & 310.5 & 63.2 & 117.3 & 55,44 \\
MDA-MB231 & 176.6 & 129 & 187.8 & 62,33 \\
\hline HEK293 & 327.8 & 398.8 & 373.1 & 24,33 \\
\hline
\end{tabular}

Light red, low activity; yellow, moderate activity; green, high activity.

The cytotoxic activities of $\mathbf{1}, \mathbf{2}, \mathbf{3}$, and Fluorouracil (5-FU) standard (positive control) against MCF-7, DLD-1, ECC-1, DU-145, PC3, MDA-MB231 cancer cell lines and HEK293 normal cell line were tested after the compounds interacted with the cells for $24 \mathrm{~h}$. The results were analyzed by means of cell viability curves and given with $\mathrm{IC}_{50}$ values in a concentration range from 0 to $200 \mu \mathrm{M}$. The half-maximal inhibitory concentration ( IC $_{50}$ ) is defined as the concentration required to reduce the size of the cell population by $50 \%$. The IC $_{50}$ values obtained for ligand and its complexes against the tested cell lines are given in Table 1 and the relation between \% viable cells and the compound concentration is plotted to get the survival curve of each cell line (Figure 3 ).

Judging by the $\mathrm{IC}_{50}$ values, copper complex showed the highest cytotoxicity in comparison with the ligand and the manganese complex. Even though all the synthesized compounds showed lower cytotoxicity on cancer cells than the standard medication, 5-FU, their cytotoxicity on normal healthy cells (HEK293) is more selective than 5-FU. Especially copper complex is noteworthy as it showed close IC $_{50}$ values to those of standard 5-FU against MCF-7, PC-3 and DU-145 and its cytotoxicity on healthy HEK293 cells is the lowest. 

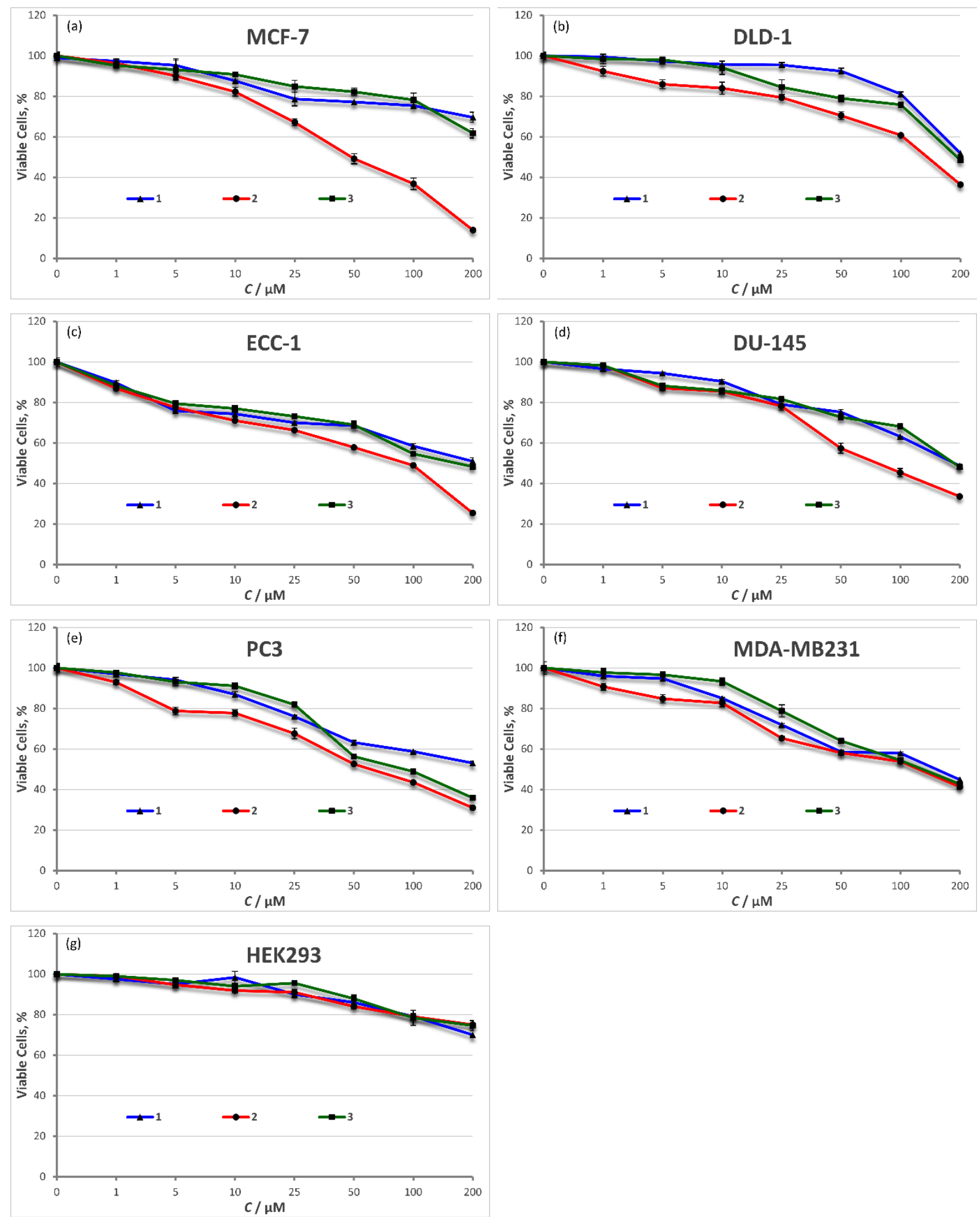

Figure 3. Plot of the \% viable cells at various concentrations of $\mathbf{1}, \mathbf{2}$, and $\mathbf{3}$ against MCF7 (a), DLD-1 (b), ECC-1 (c), DU-145 (d), PC3 (e), MDA-MB231 (f) tumor cell lines and HEK293 (g) normal cell line (Concentrations in $\mu \mathrm{M}$ ).

As seen in Figure 3, the antiproliferative activity of the ligand and its complexes against the tested cells showed a dose dependent manner. Cell growth inhibition of the compounds increased gradually with the concentration increase. In our study, the results of the cytotoxic assays exhibited that the metal complexes have better bioactivity towards MCF- 
7, DLD-1, ECC-1, DU-145, PC3, and MDA-MB231 cell lines in comparison with the free Schiff base ligand (1). The most potent effect was observed especially with $\mathrm{Cu}$ (II) complex (2). The analysis of the IC $_{50}$ values suggests that chelation enhanced the activity against the tested malignant tumor cell lines significantly with copper ion and moderately with manganese ion. The cytotoxic enhancement was highest against MCF-7 and lowest against MDA-MB231 cells. This might be attributed to the nature of the tumor type in question. Occasionally, the response to compounds may differ from cell to cell and sometimes some tumor cells deviate from the general trend as each cancer type has different causes, morphology and metabolism.

The enhancement of the cytotoxicity towards tumor cells upon chelation might be elucidated by Overtone's concept of cell permeability (40) and Tweedy's chelation theory (41). Overtone's concept of cell permeability denotes that the lipid membrane around the cell favors the passage of lipophilic materials thus lipo-solubility is an important factor which controls the bioactivity. Also, the process of chelation dominantly affects the overall biological behavior of the compounds because chelation considerably reduces the polarity of the metal ion by partially sharing its positive charge with donor groups. Moreover, it increases the delocalization of n-electrons over the whole chelate ring and enhances the lipophilicity. This increased lipophilicity probably leads to bring down the solubility and permeability barriers of cell, which in turn enhances the bioavailability of the compounds on one hand and potentiality at another.

Interestingly, chelation did not enhance the cytotoxicity of the ligand towards healthy HEK293 cells. IC 50 values showed that metal complexation rather slightly decreased the toxicity of the ligand against HEK293 cells. Copper complex (2) which had the highest cytotoxic activity towards the tested cancer cells exhibited the lowest cytotoxicity towards this healthy cell line followed by manganese complex (3). This selective sensitivity might be attributed to metabolic difference between healthy and tumor cells. It is well known that cancer cells use energy differently than most cell types so there are metabolic differences between healthy cells and cancer cells (42). This is very important because selectivity and good cytotoxic efficacy are some of the basic requirements of an anticancer agent. The unmanageable side effects caused by the unselectivity of most of the current chemotherapy drugs to treat cancer are a challenging and continuing problem. Many popular chemotherapeutics have good cytotoxicity but poor selectivity. 


\section{CONCLUSION}

In conclusion, a novel $\mathrm{N}_{2} \mathrm{O}_{2}$ type Schiff base ligand and its $\mathrm{Cu}$ (II) and $\mathrm{Mn}$ (III) complexes were synthesized and characterized by spectroscopic methods. From the spectral and analytical data and the magnetic behavior of the complexes, the square planar and octahedral geometry have been proposed for the $\mathrm{Cu}$ (II) and $\mathrm{Mn}$ (III) complexes, respectively. Due to the long distance between the two donor sites of the ligand, a tetradentate coordination to a metal center is unattainable; thus, the ligand coordinates to two different metal atoms bidentately forming a binuclear double stranded helical structure in a 2:2 (metal to ligand) stoichiometry. This structural determination, which is perfectly consistent with the similar complexes in the literature, is further supported by the elemental analysis, LC-MS, and the magnetic susceptibility data. Cytotoxic activity studies against the tested cancerous cell lines showed that copper chelation improved the cytotoxic activity of the ligand significantly whereas $\mathrm{Mn}$ complexation had a slight improvement. Thus, the intensity of the enhancement is determined by the metal employed in the complex. Surprisingly, metal chelation showed just opposite effect towards healthy cells. Copper complex (2) which had the most potent cytotoxicity towards cancer cells showed the least detrimental effects on healthy HEK293 cells. That is, especially copper complex was found to exert a selective cytotoxicity against malignant cell lines which is considered as the key to the future of cytotoxic therapy.

\section{REFERENCES}

1. Schiff $\mathrm{H}$. Mittheilungen aus dem Universitätslaboratorium in Pisa: eine neue Reihe organischer Basen. Justus Liebigs Annalen der Chemie. 1864 Jan 1;131(1):118-9.

2. Luo XF, Hu X, Zhao XY, Goh SH, Li XD. Miscibility and interactions in blends and complexes of poly (4-methyl-5-vinylthiazole) with proton-donating polymers. Polymer. 2003 Aug 31;44(18):5285-91.

3. Stryer L. Biochemistry, 4th Ed. New York: W H Freeman \& Co; 1995.

4. Baumgrass R, Weiwad M, Erdmann F, Liu JO, Wunderlich D, Grabley S, Fischer G. Reversible inhibition of calcineurin by the polyphenolic aldehyde gossypol. Journal of Biological Chemistry. 2001 Dec 21;276(51):47914-21.

5. Pfeiffer $P$, Breith $E$, Lübbe $E$, Tsumaki T. Tricyclic ortho-condensed partial valence rings. Justus Liebigs Ann Chem. 1933;503:84-130. 
6. Hernández-Molina R, Mederos A. 1.19 - Acyclic and Macrocyclic Schiff Base Ligands. In: Meyer TJ, McCleverty JA, editors. Comprehensive Coordination Chemistry II. Oxford: Pergamon; 2003. p. 41146.

7. Andruh M, Tuna F. Organic Chemistry for Inorganic Chemists. Unsymmetrical Schiff-Bases Derived from 3-Formyl-Salycilic Acid as Versatile Ligands in Coordination Chemistry. In: Cato MA, editor. Focus on Organometallic Chemistry Research. Hauppauge, New York: Nova Science Publishers; 2005. p. 144-66.

8. Rosu T, Pahontu E, Ilies DC, Georgescu R, Mocanu M, Leabu M, Shova S, Gulea A. Synthesis and characterization of some new complexes of $\mathrm{Cu}$ (II), Ni (II) and V (IV) with Schiff base derived from indole-3-carboxaldehyde. Biological activity on prokaryotes and eukaryotes. European journal of medicinal chemistry. 2012 Jul 31;53:380-9.

9. Sinha D, Tiwari AK, Singh S, Shukla G, Mishra P, Chandra H, Mishra AK. Synthesis, characterization and biological activity of Schiff base analogues of indole-3-carboxaldehyde. European journal of medicinal chemistry. 2008 Jan 31;43(1):160-5.

10. Shukla G, Tiwari AK, Sinha D, Srivastava R, Cahndra H, Mishra AK. Synthesis and assessment of $99 \mathrm{mTc}$ chelate-conjugated alendronate for development of specific radiopharmaceuticals. Cancer Biotherapy and Radiopharmaceuticals. 2009 Apr 1;24(2):209-14.

11. Vicini P, Geronikaki A, Incerti M, Busonera B, Poni G, Cabras CA, et al. Synthesis and biological evaluation of benzo [d] isothiazole, benzothiazole and thiazole Schiff bases. Biorg Med Chem. $2003 ; 11(22): 4785-9$.

12. Eckhardt S. Recent progress in the development of anticancer agents. Curr Med Chem Anticancer Agents. 2002;2(3):419-39.

13. Sierra JR, Cepero V, Giordano S. Molecular mechanisms of acquired resistance to tyrosine kinase targeted therapy. Molecular cancer. 2010 Apr 12;9(1):75.

14. Qin DD, Yang ZY, Zhang FH, Du B, Wang P, Li TR. Evaluation of the antioxidant, DNA interaction and tumor cell cytotoxicity activities of Copper (II) complexes with Paeonol Schiff-base. Inorganic Chemistry Communications. 2010 Jun 30;13(6):727-9.

15. Sampath K, Sathiyaraj S, Jayabalakrishnan C. DNA binding, DNA cleavage, antioxidant and cytotoxicity studies on ruthenium (II) complexes of benzaldehyde 4-methyl-3-thiosemicarbazones. Spectrochimica Acta Part A: Molecular and Biomolecular Spectroscopy. 2013 Mar 15;105:582-92.

16. Sampath K, Sathiyaraj S, Jayabalakrishnan C. Evaluation of DNA-binding, DNA cleavage, antioxidant and cytotoxic activity of mononuclear ruthenium (II) carbonyl complexes of benzaldehyde 
4-phenyl-3-thiosemicarbazones. Spectrochimica Acta Part A: Molecular and Biomolecular Spectroscopy. 2013 Nov 30;115:287-96.

17. Aly MR, Fodah HH, Saleh SY. Antiobesity, antioxidant and cytotoxicity activities of newly synthesized chalcone derivatives and their metal complexes. European journal of medicinal chemistry. 2014 Apr 9;76:517-30.

18. Lee SM, Ali HM, Sim KS, Malek SN, Lo KM. Synthesis, characterization and biological activity of diorganotin complexes with ONO terdentate Schiff base. Inorganica Chimica Acta. 2013 Sep $1 ; 406: 272-8$.

19. Naseri Z, Kharat AN, Banavand A, Bakhoda A, Foroutannejad S. First row transition metal complexes of thienyl substituted terpyridine: Structural, photophysical and biological studies. Polyhedron. 2012 Feb 9;33(1):396-403.

20. Zhao X, Loo SC, Lee PP, Tan TT, Chu CK. Synthesis and cytotoxic activities of chloropyridylimineplatinum (II) and chloropyridyliminecopper (II) surface-functionalized poly (amidoamine) dendrimers. Journal of inorganic biochemistry. 2010 Feb 28;104(2):105-10.

21. Sathiyaraj S, Sampath K, Raja G, Butcher RJ, Gupta SK, Jayabalakrishnan C. DNA binding/cleavage, antioxidant and cytotoxic activities of water soluble cobalt (II) and copper (II) antipyrine complexes. Inorganica Chimica Acta. 2013 Sep 1;406:44-52.

22. Khoo TJ, bin Break MK, Crouse KA, Tahir MI, Ali AM, Cowley AR, Watkin DJ, Tarafder MT. Synthesis, characterization and biological activity of two Schiff base ligands and their nickel (II), copper (II), zinc (II) and cadmium (II) complexes derived from S-4-picolyldithiocarbazate and X-ray crystal structure of cadmium (II) complex derived from pyridine-2-carboxaldehyde. Inorganica Chimica Acta. 2014 Mar 24;413:68-76.

23. Chaves JD, Neumann F, Francisco TM, Corrêa CC, Lopes MT, Silva H, Fontes AP, de Almeida MV. Synthesis and cytotoxic activity of gold (I) complexes containing phosphines and 3-benzyl-1, 3thiazolidine-2-thione or 5-phenyl-1, 3, 4-oxadiazole-2-thione as ligands. Inorganica Chimica Acta. 2014 Apr 1;414:85-90.

24. Kovala-Demertzi D, Staninska M, Garcia-Santos I, Castineiras A, Demertzis MA. Synthesis, crystal structures and spectroscopy of meclofenamic acid and its metal complexes with manganese (II), copper (II), zinc (II) and cadmium (II). Antiproliferative and superoxide dismutase activity. Journal of inorganic biochemistry. 2011 Sep 30;105(9):1187-95.

25. Cucos P, Tuna F, Sorace L, Matei I, Maxim C, Shova S, Gheorghe R, Caneschi A, Hillebrand M, Andruh M. Magnetic and luminescent binuclear double-stranded helicates. Inorganic chemistry. 2014 Jul 7;53(14):7738-47. 
26. Hasi QM, Fan Y, Yao XQ, Hu DC, Liu JC. Synthesis, characterization, antioxidant and antimicrobial activities of a bidentate Schiff base ligand and its metal complexes. Polyhedron. 2016 Apr 18;109:7580.

27. Mondal AK, Parmar VS, Biswas S, Konar S. Tetrahedral M II based binuclear double-stranded helicates: single-ion-magnet and fluorescence behaviour. Dalton Transactions. 2016;45(11):454857.

28. A. Earnshaw, Introduction to Magnetochemistry, Academic Press, London, 1968, p. 4.

29. Arslan F, Odabaşoğlu M, Ölmez H, Büyükgüngör O. Synthesis, crystal structure, spectral and thermal characterization of bis (o-vanillinato)-triethylenglycoldiiminecopper (II) and bis [(R)-(-)hydroxymethylpropylimine o-vanillinato] copper (II). Polyhedron. 2009 Sep 23;28(14):2943-8.

30. Liu SB, Bi CF, Fan YH, Zhao Y, Zhang PF, Luo QD, Zhang DM. Synthesis, characterization and crystal structure of a new fluorescent probe based on Schiff Base for the detection of Zinc (II). Inorganic Chemistry Communications. 2011 Aug 31;14(8):1297-301.

31. Ejidike IP, Ajibade PA. Synthesis, characterization and biological studies of metal (II) complexes of (3E)-3-[(2-\{(E)-[1-(2, 4-dihydroxyphenyl) ethylidene] amino\} ethyl) imino]-1-phenylbutan-1one Schiff base. Molecules. 2015 May 27;20(6):9788-802.

32. Yaftian MR, Rayati S, Safarbali R, Torabi N, Khavasi HR. A new tetradentate N2O2-type Schiff base ligand. Synthesis, extractive properties towards transition metal ions and X-ray crystal structure of its nickel complex. Transition Metal Chemistry. 2007 Mar 27;32(3):374-8.

33. Shelke VA, Jadhav SM, Patharkar VR, Shankarwar SG, Munde AS, Chondhekar TK. Synthesis, spectroscopic characterization and thermal studies of some rare earth metal complexes of unsymmetrical tetradentate Schiff base ligand. Arabian Journal of Chemistry. 2012 Oct 31;5(4):5017.

34. Xinde Z, Chenggang W, Zhiping L, Zhifeng L, Zishen W. Synthesis and Biological Activity of the Schiff Base N, N'-bis (Salicylidene) thiourea and Its Complexes of Copper (II), Nickel (II) and Zinc (II). Synthesis and Reactivity in Inorganic and Metal-Organic Chemistry. 1996 Jul 1;26(6):955-66.

35. Abd-Elzaher MM. Spectroscopic characterization of some tetradentate Schiff bases and their complexes with nickel, copper and zinc. Journal of the Chinese Chemical Society. 2001 Apr $1 ; 48(2): 153-8$.

36. Guguloth H. Synthesis, Characterization and Biological Studies: N2O2 Donor Novel Schiff Base Ligands and Their $\mathrm{Co}(\mathrm{II}), \mathrm{Ni}(\mathrm{II}), \mathrm{Cu}(\mathrm{II}), \mathrm{Rh}(\mathrm{III}), \mathrm{Pd}(\mathrm{II})$ Metal Complexes. International Journal of Pharmacy and Biological Sciences. 2015 Jul 1; 5(3):102-118. 
37. Jeslin Kanaga Inba P, Annaraj B, Thalamuthu S, Neelakantan MA. Cu (II), Ni (II), and Zn (II) complexes of salan-type ligand containing ester groups: synthesis, characterization, electrochemical properties, and in vitro biological activities. Bioinorganic chemistry and applications. $2013 \mathrm{Jul}$ $25 ; 2013$.

38. Talukder P, Datta A, Mitra S, Rosair G. Square planar complexes of $\mathrm{Cu}$ (II) with an $\mathrm{N} 2 \mathrm{O}$ donor set of a new Schiff base ligand: synthesis and structural aspects. Zeitschrift für Naturforschung B. 2004 Jun 1;59(6):655-60.

39. Lever A B P. Inorganic Electronic Spectroscopy (2nd edition). Amsterdam- New York: Elsevier (1984).

40. Anjaneyulu Y, Rao RP. Preparation, characterization and antimicrobial activity studies on some ternary complexes of $\mathrm{Cu}$ (II) with acetylacetone and various salicylic acids. Synthesis and Reactivity in Inorganic and Metal-Organic Chemistry. 1986 Jan 1;16(2):257-72.

41. Tweedy B. Plant extracts with metal ions as potential antimicrobial agents. Phytopathology. $1964 ; 55: 910-4$.

42. Warburg O, Wind F, Negelein E. The metabolism of tumors in the body. The Journal of general physiology. 1927 Mar 7;8(6):519. 
